\title{
Pharmacological studies of ethanolic extracts of Maytenus rigida Mart (Celastraceae) in animal models
}

\author{
Vanda Lucia dos Santos*, Viviam Bruna Machado Costa, Maria de Fátima Agra, Bagnólia \\ Araújo da Silva, Leônia Maria Batista
}

Laboratório de Tecnologia Farmacêutica, Universidade Federal da Paraíba, Cx. Postal 5009, 58051-970, João Pessoa, PB, Brazil

\begin{abstract}
RESUMO: "Estudo farmacológico do extrato etanólico de Maytenus rigida Mart (Celastraceae) em modelos animais". O extrato etanólico bruto (EEOH) da casca de Maytenus rigida Mart (Celastraceae) uma planta da medicina popular do Brasil, foi testado para a atividade antiinflamatória, antiúlcera e antidiarréica em modelos animais. Não foi observado sinal de toxicidade aguda nos animais tratados com doses elevadas do EEOH $(5000 \mathrm{mg} / \mathrm{kg}$, v.o. ou $2000 \mathrm{mg} / \mathrm{kg}$ i.p.). O extrato nas doses de 250,500 e $750 \mathrm{mg} / \mathrm{kg}$ mostrou um significante efeito inibitório $(\mathrm{P}<0,01)$ no edema de pata induzido por carragenina e exibiu propriedade protetora contra a ulceração induzida por etanol em ratos. Também uma atividade antidiarréica $(\mathrm{P}<0,01)$ foi observada na diarréia induzida por óleo de rícino em camundongos. O trânsito intestinal foi reduzido significativamente $(\mathrm{P}<0.01)$, porém o pré-tratamento não reduziu o peso do conteúdo intestinal em ratos. Os resultados dão suporte à utilização de Maytenus rigida na medicina popular do Brasil para o tratamento da inflamação, da úlcera e da diarréia.
\end{abstract}

Unitermos: Maytenus rigida, Celastraceae, antiinflamatória, antiúlcera, antidiarréica.

\begin{abstract}
The crude ethanol extract (EEOH) of the bark of Maytenus rigida Mart (Celastraceae) a plant used in Brazil herbal traditional medicine, was tested for anti-inflammatory, antiulcer and antidiarrhoeal activities in animal models. No acute toxicological sign was observed in animals treated with the highest dose $(5000 \mathrm{mg} / \mathrm{kg}$, p.o. or $2000 \mathrm{mg} / \mathrm{kg}$ i.p.) of EEOH. The extract doses of 250,500 or $750 \mathrm{mg} / \mathrm{kg}$ revealed a significant inhibitory effect $(\mathrm{P}<0,01)$ in carrageenin-induced rat paw oedema and exhibited ulcer-protective properties against ethanolinduced ulceration in rats. An anti-diarrhoeal activity $(\mathrm{P}<0.01)$ was also observed in castor-oilinduced diarrhoeal in mice. The intestinal transit was significantly $(P<0.01)$ reduced, however the pretreatment did not reduce the weight of intestinal contents. These results support the popular applications of Maytenus rigida for the treatment of inflammation, ulcer and diarrhoea in Brazil herbal traditional medicine.
\end{abstract}

Keywords: Maytenus rigida, Celastraceae, anti-inflammatory, antiulcer, anti-diarrhoeal.

\section{INTRODUCTION}

Recently, there has been a return of the use of plants for the treatment of different diseases, nevertheless, many plants have not been studied for their the claimed biological activity, and thus it is necessary to verify the activity through a pharmacological study.

Plant extracts of the Celastraceae have been used for centuries as insecticide in traditional agriculture, and also for the treatment of many stomachal complications, fever, rheumatoid arthritis and cancer. The Maytenus genus is the largest one of the Celastraceae family. Currently, there are about 80 species recognized and distributed all over Brazilian territory (Joffily; Vieira, 2005; Brandão et al 2006).

Many biological activities of this genus were determined experimentally as antiulcerogenic and analgesic (Gonzalez et al., 2001; Silva et al., 2005), antiulcer (Souza-Formigoni et al., 1991; Tabach; Oliveira, 2003; Ferreira et al., 2004; Jorge et al., 2004), antinociceptive, anti-inflammatory (Jorge et al., 2004), antioxidant (Vellosa et al., 2006; Melo et al., 2001) activity of Maytenus ilicifolia, antimicrobial (Kloucek et al., 2007) and antileishmanial (Perez-Victoria et al., 1999) activity of Maytenus macrocarpa, antimutagenic, antioxidant and antimicrobial of M. krukovii (Bruni et al., 2006), DNA Polymerase $\beta$-Lyase inhibitory activity from Maytenus putterlickoides (Feng et al., 2004). Maytenus rigida Mart. (Celastraceae) popularly known as "bom-nome", "bom-homem" or "pau-decolher" is considered a native plant in the northeast of Brazil (Andrade-Lima 1989; Rocha et al., 2004; Agra et al., 2007). In folk medicine, the decoction obtained from the bark of Maytenus rigida is used for the treatment 
of inflammatory diseases and gastrointestinal disorders as diarrhoea, dysentery and ulcer (Rocha et al., 2004). Despite the popular use of this species as a medicinal plant, there are no data about its pharmacological effect.

This study aimed at the investigation into the antiinflamatory, gastric antiulcer and antidiarrhoeal activities of the EtOH extract of the barks of Maytenus rigida in animal models.

\section{MATERIAL AND METHODS}

\section{Animals}

Male Swiss albino mice (27-35 g) and male Wistar rats (180-250 g) obtained from the Central Animal House of the Laboratório de Tecnologia Farmacêutica (LTF) of the Universidade Federal da Paraíba (UFPB) were used. The animals were fed by a certified Nuvilab CR-diet, with free access to tap water, and housed on a $12 \mathrm{~h} \mathrm{light/dark} \mathrm{cycle} \mathrm{at} 60 \pm 1 \%$ humidity and a temperature of $21.5 \pm 2{ }^{\circ} \mathrm{C}$. The experimental protocols were approved by the institutional Committee for Ethics Animal Research (LTF/UFPB), protocol number
0513/05

\section{Plant material and ethanolic extracts preparation}

Maytenus rigida Mart was collected in the city of Aroeira, Paraíba state, Brazil and identified by Dr. Maria de Fátima Agra, the botanist from the LTF/ UFPB. A voucher Agra et al. 3316 (JPB) was deposited in the Herbarium Lauro Pires Xavier of the Departament of Botany of the UFPB, Brazil. The bark (3500 g) of Maytenus rigida Mart, was dried in oven at $50{ }^{\circ} \mathrm{C}$ for 4 days, powdered and macerated with $96 \%$ ethanol for 3 days. The solution was filtered and concentrated under reduced pressure (rotaevaporator) at $40{ }^{\circ} \mathrm{C}$. The yield (w/w) of the crude ethanol extract (EEOH) was 14\%.

\section{Drugs}

Cimetidine $(100 \mathrm{mg} / \mathrm{kg}$ v.o.), atropine $(10$ $\mathrm{mg} / \mathrm{kg}$ v.o. $)$, carrageenin $(0.1 \mathrm{~mL}$ of a $1.0 \%$ subplantar suspension) obtained from Sigma Chemical Co. St. Louis, Mo, (USA), lansoprazole (30 mg/kg p.o.), Medley, Brazil, indomethacin (20 mg/kg p.o.), ethanol from Merck, Germany, loperamida (2 $\mathrm{mg} / \mathrm{kg}$ v.o.),

Table 1. Effects of indomethacin and EEOH of Maytenus rigida on Carrageenan-induced paw oedema in rats.

\begin{tabular}{lcccc}
\hline Treatment & Dose & \multicolumn{3}{c}{ paw volume $(\mathrm{mL})$} \\
\cline { 3 - 5 } & $\mathrm{mg} / \mathrm{kg}$ & $1 \mathrm{~h}$ & $2 \mathrm{~h}$ & $3 \mathrm{~h}$ \\
\hline Saline & & $0.35 \pm 0.08$ & $0.65 \pm 0.07$ & $0.74 \pm 0.07$ \\
Indomethacin & 20 & $0.20 \pm 0.04 * *$ & $0.32 \pm 0.07 * *$ & $0.37 \pm 0.07 * *$ \\
& & $(43 \%)$ & $(51 \%)$ & $(50 \%)$ \\
EEOH & 250 & $0.29 \pm 0.09$ & $0.46 \pm 0.09 * *$ & $0.54 \pm 0.08 * *$ \\
& & $(17 \%)$ & $(29 \%)$ & $(27 \%)$ \\
& 500 & $0.23 \pm 0.05 * *$ & $0.35 \pm 0.08 * *$ & $0.48 \pm 0.07 * *$ \\
& & $(34 \%)$ & $(46 \%)$ & $(35 \%)$ \\
& 750 & $0.17 \pm 0.06 * *$ & $0.32 \pm 0.06 * *$ & $0.39 \pm 0.07 * *$ \\
& $(51 \%)$ & $(51 \%)$ & $(47 \%)$ \\
\hline
\end{tabular}

The results are mean \pm S.D. of mice. ANOVA $\mathrm{F}_{(4,70)}=72$ followed by Bonferroni's test $* * \mathrm{p}<0,01$ compared to the saline control.

The $\%$ of inhibition vs. control are reported in brackets.

Table 2. Effects of lansoprazole and EEOH of Maytenus rigida on ethanol-induced gastric ulcers in rats.

\begin{tabular}{lccc}
\hline Treatment & $\begin{array}{c}\text { Dose } \\
(\mathrm{mg} / \mathrm{kg})\end{array}$ & UI & $\begin{array}{c}\text { Inhibition } \\
(\%)\end{array}$ \\
\hline Saline & - & $130 \pm 7.9$ & - \\
Lansoprasole & 100 & $45 \pm 7.3^{* *}$ & 65 \\
EEOH & 125 & $117 \pm 8.8$ & 10 \\
& 250 & $63 \pm 5.9^{* *}$ & 52 \\
& 500 & $17 \pm 2.7^{* *}$ & 87 \\
& 750 & $7 \pm 2.6^{* *}$ & 95 \\
\hline
\end{tabular}

Results (UI) are mean \pm S.D. of mice. ANOVA $\mathrm{F}_{(5,30)}=354.57$ followed by Dunnett's test. $* * \mathrm{p}<0.01$ compared to the saline control. 
Table 3. Effects of loperamide and EEOH of Maytenus rigida on castor oil-induced diarrhoea in mice.

\begin{tabular}{lcccc}
\hline \multicolumn{1}{c}{ Treatment } & $\begin{array}{c}\text { Dose } \\
(\mathrm{mg} / \mathrm{kg})\end{array}$ & $\begin{array}{c}\text { Total number of } \\
\text { faeces in } 4 \mathrm{~h}\end{array}$ & $\begin{array}{c}\text { Number of wet faeces in } 4 \\
\mathrm{~h}\end{array}$ & \% Inhibition of diarrhoea \\
\hline saline & - & $25 \pm 2.07$ & $17 \pm 2.07$ & - \\
loperamide & 10 & $8 \pm 1.58^{* *}$ & $5 \pm 1.34^{* *}$ & 68 \\
EEOH & 250 & $12 \pm 2.70^{* *}$ & $8 \pm 1.58^{* *}$ & 52 \\
& 500 & $8 \pm 1.64^{* *}$ & $3 \pm 1.30^{* *}$ & 68 \\
& 750 & $5 \pm 1.22^{* *}$ & $2 \pm 0.55^{* *}$ & 80 \\
\hline
\end{tabular}

The results are the mean \pm S.D. ANOVA $\mathrm{F}_{(4,20)}=88$ for total number of faeces and $\mathrm{F}_{(4,20)}=95$ for number of wet faeces followed by Dunnett's test. ${ }^{* *} \mathrm{p}<0.01$ compared to the control group.

Table 4. Effects of atropine and EEOH of Maytenus rigida on small intestinal transit in rats.

\begin{tabular}{lccc}
\hline Treatment & Dose $(\mathrm{mg} / \mathrm{kg})$ & Peristaltic index & \% Inhibition \\
\hline saline & - & $83 \pm 6.24$ & - \\
atropine & 2 & $53 \pm 2.45^{* *}$ & 36 \\
EEOH & 250 & $61 \pm 4.23^{* *}$ & 26 \\
& 500 & $52 \pm 4.89^{* *}$ & 37 \\
& 750 & $47 \pm 1.20^{* *}$ & 43
\end{tabular}

The results are the mean \pm S.D. of mice. ANOVA $\mathrm{F}_{(4,24)}=63$ followed by Dunnett's test. ${ }^{*} \mathrm{p}<0.01$ compared to the control group.

Table 5. Effect of atropine and EEOH Maytenus rigida on intraluminal fluid accumulation in the small intestine of rats.

\begin{tabular}{lcc}
\hline Treatment & Dose $(\mathrm{mg} / \mathrm{kg})$ & Weight of intestinal content $(\mathrm{g})$ \\
\hline saline & - & $3.12 \pm 0.43$ \\
atropine & 2 & $1.95 \pm 0.17^{* *}$ \\
EEOH & 250 & $2.82 \pm 0.22$ \\
& 500 & $3.10 \pm 0.21$ \\
& 750 & $3.35 \pm 0.16$
\end{tabular}

The results are the mean \pm S.D. of mice. ANOVA $\mathrm{F}_{(4,24)}=27$ followed by Dunnett's test. $* * \mathrm{p}<0.01$ compared to the control group.

castor oil ( $0.7 \mathrm{~mL} /$ animals), deactivated charcoal ( $5 \%$ v.o.), gum acacia (5\% v.o.). An ethanol extract (EEOH), from the bark of Maytenus rigida Mart was dissolved in $0.9 \%$ of saline $(\mathrm{w} / \mathrm{v})$.

\section{Acute toxicity studies}

Acute toxicity studies were performed in mice of either sex as described by Souza Brito (1995). For these studies, mice were divided into five groups, containing 10 animals each. The treated group received EEOH extract in doses of $650,1250,2500$ or $5000 \mathrm{mg} /$ $\mathrm{kg}$ (p.o.) or $250,500,1000$ or $2000 \mathrm{mg} / \mathrm{kg}$ (i.p.) animal weight. Mice were carefully observed 0,$5 ; 1 ; 2 ; 3 ; 4$;
24; 48 and $72 \mathrm{~h}$ after the treatment to assess possible clinical or toxicological symptoms.

\section{Carrageenin-induced paw oedema in rats}

Anti-inflammtory activity was evaluated on basis of the inhibition of the carrageenin-induced hind paw oedema (Winter et al., 1962). The rats were divided into control (salina, $10 \mathrm{ml} / \mathrm{kg}$, p.o.), positive control (indomethacin $20 \mathrm{mg} / \mathrm{kg}$ p.o.) and test groups (EtOH extract 250,500 or $750 \mathrm{mg} / \mathrm{kg}$ p.o.) containing five mice in each group. Paw oedema was induced by the injection of $0.1 \mathrm{~mL}$ of $1.0 \%$ carrageenin suspension in the subplantar region of the left hindpaw. The paw 
volume was determined before any treatment (basal volume) and measured at 1, 2 and $3 \mathrm{~h}$ after carrageenin injection with a plethysmometer (UGO Basile, Italy). The extract or indomethacin were administered $60 \mathrm{~min}$ before carrageenin injection.

\section{Ethanol-induced ulcer}

The experiment was performed according to Morimoto et al. (1991). After a $24 \mathrm{~h}$ fasting, rats ( $n$ $=6$ ) received an oral administration of EEOH from Maytenus rigida Mart $(125,250,500$ or $750 \mathrm{mg} / \mathrm{kg})$, lansoprazole $(30 \mathrm{mg} / \mathrm{kg})$ or saline $(10 \mathrm{~mL} / \mathrm{kg})$. One hour after treatment, all rats received $1 \mathrm{~mL}$ of ethanol to induce gastric ulcer. The animals were killed $1 \mathrm{~h}$ after treatment with the ulcerogenic agent and the stomachs removed and opened along the greater curvature. The ulcerative lesion index (U.L.I.) was calculated according to the methodology described by Szelenyi; Thiemer (1978).

\section{Castor oil-induced diarrhea}

The method, described by Awouters et al. (1978) with modification, was followed for this study. Briefly, the animals were divided into control (saline), positive control (loperamide $10 \mathrm{mg} / \mathrm{kg}$ ) and test groups (EEOH 250,500 or $750 \mathrm{mg} / \mathrm{kg}$ ), containing five mice in each group. Each animal was placed in an individual cage, the floor was lined with blotting paper and changed every hour. Diarrhoea was induced by oral administration of $0.7 \mathrm{ml}$ castor oil to each mouse, $30 \mathrm{~min}$ after the above treatments. During an observation period of $4 \mathrm{~h}$, the total number of faecal output and the number of diarrhoeic faeces excreted by the animals were recorded.

\section{Normal intestinal transit and intestinal fluid accumulation}

The method, described by Rao et al. (1997), was followed in this study. The animals were left to starve for $12 \mathrm{~h}$ prior the experiment but were allowed free access to water. The animals were divided into control (salina, $10 \mathrm{~mL} / \mathrm{kg}$, p.o.), positive control (atropine sulphate $2 \mathrm{mg} / \mathrm{kg}$ p.o.) and test groups (EtOH extract 250,500 or $750 \mathrm{mg} / \mathrm{kg}$ p.o.) containing five rats in each. After $60 \mathrm{~min}$, standard charcoal meal (1 $\mathrm{mL} /$ rat of a $5 \%$ deactivated charcoal suspension in $5 \%$ gum acacia) were given to mice orally. Animals were sacrificed $30 \mathrm{~min}$ after administration of charcoal meal and the small intestine immediately isolated. Peristaltic index for each mouse was expressed as percentage of the distance traveled by the charcoal meal relative to the total length of the small intestine from pyloric sphincter to ileo-caecal junction of each animal. The intestinal fluid accumulation was indirectly analyzed by enteropooling assay (Rao et al., 1997). Briefly, the intestine was reweighed and the difference between full and empty intestines was calculated.

\section{Statistical analysis}

Data was analysed using the program Instat ${ }^{\circledR}$. The results are expressed as the mean \pm S.D. Statistical significance between groups was assessed by one-way analysis of variance (ANOVA) followed by Dunnett's or Bonferroni's test .with the level of significance $p<$ 0.05 .

\section{RESULTS AND DISCUSSION}

As part of this pharmacological study, the acute toxicity of the EEOH obtained from Maytenus rigida Mart in mice was first investigated. Increasing doses of EEOH were administered orally $(650,1250,2500$ or $5000 \mathrm{mg} / \mathrm{kg}$ ) and intraperitoneally $(250,500,1000$ or $2000 \mathrm{mg} / \mathrm{kg}$ ). In these doses, no signs and symptoms of acute toxicity were observed in all treated mice.

Inflammation is one of the most important processes involved in the defense of an organism; however, it often progresses to painful or chronically harmful diseases needing pharmacological treatment. The inflammatory response involves many effector mechanisms which produce a multiplicity of vascular and cellular reactions. (Ward, 1994).

During the progression of carrageenan-induced edema there is a release of some mediators (Winter et al., 1962; Chattapadhyay et al., 2002). The initial phase is attributed to the release of histamine and 5-HT. A second phase is mediated by kinins and finally in a third phase, the mediator is prostaglandin (Di Rosa et al., 1971; Holsapple et al., 1980). The acute phase of the inflammation is characterized by local vasodilatation and increased capillary permeability resulting in an exudation of fluid the interstitial space (Pedernera et al., 2006).

Carrageenin-induced paw oedema has been frequently used to assess the anti-oedematous effect of natural products. In this model of inflammation the EEOH at 250,500 and $750 \mathrm{mg} / \mathrm{kg}$ inhibited the formation of edema after carrageenin injection with maximum inhibition in paw volume of 29,46 and 51 $\%$ respectively in the second hour (Table 1) compared to the saline control, suggesting that inhibition kinins and/or prostaglandins.

Peptic ulcer is a common injury that may be induced by a variety of factors, such as ethanol, stress, smoking, nutritional deficiencies and noxious agents, including non-steroidal anti-inflammatory drugs (NSAIDs) (To et al., 2001).

Injection of absolute ethanol into the gastric lumen induced gross lesions in the glandular part of stomach (Natele et al, 2001). This gastric damage may be due to stasis in gastric blood flow, which contributes to the development of the hemorrhage and

Rev. Bras. Farmacogn. Braz J. Pharmacogn 17(3): Jul./Set. 2007 
necrotic aspects of tissue injury. This is direct a action on the gastric epithelium also causing perturbation of mast cells and release of vasoactive mediators such as histamine (Guth et al., 1984; Oates; Hakkinen, 1988). Recent studies have demonstrated that ROS and lipid peroxidation play an important role in the pathogenesis of acute gastric damages induced by ethanol (La Casa et al., 2000). Endogenous glutathione and prostaglandin (PG) levels are also lowered by ethanol while the release of histamine, influx of calcium ions, generation of free radicals and production of leukotrienes are all increased (Glavin; Szabo, 1992). It has been demonstrated that mucosal barrier does not hinder the diffusion of ethanol into gastric mucosa. Therefore, it might be assumed that the relatively lipophilic ethanol can also be taken up by the cells (Dokmeci et al., 2005).

In the model of ethanol-induced ulcers (Table 2 ), oral administration of the EEOH at doses 250, 500 or $750 \mathrm{mg} / \mathrm{kg}$ and lansoprazole $(30 \mathrm{mg} / \mathrm{kg}$, positive control) significantly inhibited 52, 87, 95 and $65 \%$ of the ulcerogenic lesions from the ethanol over the gastric surface, respectively. This protection could reflect the inhibition of gastric secretion or an increase in the release of protective substances by the mucosa.

The delayed gastric emptying increases the absorption of orally administered anti-ulcer agents, thus promoting ulcer healing (Bertaccini; Scapignato, 1981). The extract decreased the propulsive movement of charcoal meal through the gastrointestinal tract (GIT) in a dose-dependent manner. This observation was significantly $(\mathrm{P}<0.01)$ different from what was seen in the control group (Table 4). The significant delay in gastrointestinal transit caused by EEOH of Maytenus rigida is considered to be a beneficial property in ulcer patients.

Diarrhoea is a worldwide problem, especially among children and contributes to morbidity and mortality. It is considered to be the passage of watery bowel contents at a daily rate twice that of a person's usual rate (Raffa et al, 2006). The treatment of the diarrhoeal aims at, among other objectives, to increase resistance to flow (segmental contraction, decrease propulsion and peristalsis) and to increase mucosal absorption or to decrease secretion (Burks, 1991).

Several mechanisms have been previously proposed to induce the diarrhoeal effect of castor oil (Izzo, 1996). These include inhibition of intestinal $\mathrm{Na}^{+}, \mathrm{K}^{+}$-ATPase activity to reduce normal fluid absorption (Gaginella; Bass, 1978), activation of adenylate cyclase or mucosal cAMP mediated active secretion (Gaginella et al., 1978; Capasso et al., 1994), stimulation of prostaglandin formation (Capasso et al., 1986; Galvez et al., 1993), platelet activating factor (Capasso et al., 1992; Pinto et al., 1992; Mascolo et al., 1996) and most recently nitric oxide (NO) has been claimed to contribute to the diarrhoeal effect of castor oil (Mascolo et al., 1996), that increase the permeability of the epithelial layer to calcium ions and stimulate intestinal secretion (Mascolo et al., 1993).

The EEOH exhibited anti-diarrhoeal activity in the study, when inhibiting significantly $(P<0.01)$ both the frequency of defaecation as well as the wetness of the faecal droppings in mice. The extract $(750 \mathrm{mg} / \mathrm{kg})$ produced maximum inhibition ( $80 \%$ of inhibition) of castor oil-induced diarrhoea in mice (Table 3 ).

The anti-diarrhoeal effect of the extracts may be related to an inhibition of muscle contractility and motility, as observed by the decrease in intestinal transit by charcoal meal and (Table 4 ), consequently a reduction in intestinal propulsion, but no inhibition of fluid intraluminal accumulation, where pretreatment of rats with the extract did not reduce significantly the weight of intestinal content (Table 5). Therefore, the anti-transit effect of Maytenus rigida may play an important role in its anti-diarrhoeal effect.

\section{CONCLUSION}

The results obtained in this study suggest that the ethanol extract of Maytenus rigida possesses antiinflamatory, gastric antiulcer and antidiarrhoeal activity, however other studies must be carried out to elucidate the mechanisms involved in these activities. This supports the use of the plant in traditional medicine to treat inflamatory conditions, gastric ulcer and diarrhoea.

\section{ACKNOWLEDGMENTS}

The authors like to express their sincere thanks to Dr. Temilce Simões de Asssis for revision of the English and to CAPES for the financial support.

\section{REFERENCES}

Agra MF, França PF, Barbosa-Filho JM 2007. Synopsis of the plants known as medicinal and poisonous in Northeast of Brazil. Rev Bras Farmacogn 17: 114140.

Andrade-Lima D 1989. Plantas das Caatingas. Academia Brasileira de Ciências, Rio de Janeiro: 104.

Awouters F, Niemegeers CJE, Lenaerts FM, Janssen PAJ 1978. Delay of castor oil diarrhoea in rats: a new may to evaluate inhibitors of prostaglandin biosynthesis. $J$ Pharm Pharmacol 30: 41-45.

Bertaccini G, Scapignato C 1981. Histamine H2 antagonists modify gastric emptying in rats. Brit $J$ Pharmacol 77: 434-448

Brandão MGL, Cosenza GP, Moreira RA, Monte-Mor RLM 2006. Medicinal plants and other botanical products from the Brazilian Official Pharmacopoeia. Rev Bras Farmacogn 16: 408-420.

Bruni R, Rossi D, Muzzoli M, Romagnoli C, Paganetto G, Besco E, Choquecillo F, Peralta K, Lora WS, Sacchetti G 2006. Antimutagenic, antioxidant and antimicrobial properties of Maytenus krukovii bark. 
Fitoterapia 77:538-545.

Burks TF 1991. Gastrointestinal drugs. In: Kist K (Ed.), Human Pharmacology: Molecular to Clinical. Wolfe Publishing Ltd., London, 789-800.

Capasso F, Mascolo N, Autore G, Romano V 1986. Laxatives and the production of autacoids by rat colon. $J$ Pharma Pharmacol 36: 627-629.

Capasso F, Mascolo N, Izzo AA, Gaginella TS 1994. Dissociation of castor oil-induced diarrhea and intestinal mucosal injury in rat: effect of NG-nitro1-arginine methyl ester. Brit J Pharmacol 113:11271130

Capasso F, Tavares IA, Bennet A 1992. PAF formation by human gastrointestinal mucosa/submucosa in vitro: release by ricinoleic acid, and inhibition by 5 aminosalicylic acid. J Pharm Pharmacol 44: 771772 .

Chattapadhyay RN, Chattapadhyay RR, Roy S, Maitra SK 2002. A simple method for plethysmometric measurement of paw volume of small laboratory animals in evaluation of antiinflammatory effect. Bull Calcutta Sch Trop Med 36: 5-8.

Di Rosa M, Giroud JP, Willoughby DA 1971. Study of the mediators of the acute inflammatory response induced in rats in different sites by carrageenin and turpentine. J Pathol 104:15-29.

Dokmeci D, Akpolat M, Aydogdu N, Doganay L, Turan FN 2005. L-carnitine inhibits ethanol-induced gastric mucosal injury in rats. Pharmacol Rep 57 :481-488.

Feng X, Gao Z, Li S, Jones SH, Hecht SM 2004. DNA polymerase, lyase inhibitors from Maytenus putterlickoides. J Nat Prod 67: 1744-1747.

Ferreira PM, Oliveira CN, Oliveira AB, Lopes MJ, Alzamora F, Vieira MA 2004. A lyophilized aqueous extract of Maytenus ilicifolia leaves inhibits histaminemediated acid secretion in isolated frog gastric mucosa. Planta 219: 319-324.

Gaginella TS, Bass P 1978. Laxatives: an update on mechanism of action. Life Sci 23:1001-1010

Gaginella TS, Phillips SF, Dozois RR, Go VLW 1978. Stimulation of adenylate cyclase in homogenates of isolated intestinal epithelial cells from hamsters Effects of gastrointestinal hormones, prostaglandins, and deoxycholine and recinoleic acid. Gastroenterol 74:11-15.

Galvez J, Zarzuelo A, Crespo ME, Lorente MD, Ocete MA, Jimenez J 1993. Antidiarrhoeic activity of Euphorbia hirta extract and isolation of an active flavanoid constituent. Planta Med 59: 333-336.

Glavin GB, Szabo S 1992. Experimental gastric mucosal injury: Laboratory models reveal mechanisms of pathogenesis and new therapeutic strategies. Fed Am Societ Experim Biol J 6: 825-831.

Gonzalez FG, Portela TY, Stipp EJ, Di Stasi LC 2001 Antiulcerogenic and analgesic effects of Maytenus aquifolium, Sorocea bomplandii and Zolernia ilicifolia. J Ethnopharmacol 77: 41-47.

Guth PH, Paulsen G, Nagata H 1984. Histologic and microcirculatory changes in alcohol-induced gastric lesions in the rats: effects of prostaglandin cytoprotection. Gastroenterol 87: 1083-1090.

Holsapple MP, Schuner M, Yim GKW 1980. Pharmacological modulation of edema mediated by prostaglandin, serotonin and histamine. Agents Actions 10: 368373.

Izzo AA 1996. Castor oil: an update on mechanism of action. Phytother Res 10: 109-111.

Joffily A, Vieira RC, 2005. Anatomia foliar de Maytenus Mol. emend Mol. (Celastraceae), ocorrente no Estado do Rio de Janeiro, Brasil. Acta Bot Bras 19: 549-561.

Jorge RM, Leite JP, Oliveira AB, Tagliati CA 2004 Evaluation of antinociceptive, anti-inflammatory and antiulcerogenic activities of Maytenus ilicifolia. $J$ Ethnopharmacol 94: 93-100.

Kloucek P, Svobodova B, Polesny Z, Langrova I, Smrcek S, Kokoska L 2007 Antimicrobial activity of some medicinal barks used in Peruvian Amazon. $J$ Ethnopharmacol 111: 427-9.

La Casa C, Villegas I, La Lastra C A, Motilva V, Calero M J M 2000. Evidence for protective and antioxidant properties of rutin, a natural flavone, against ethanol induced gastric lesions. J Ethnopharmacol 71: 4553.

Mascolo N, Izzo AA, Autore G, Barbato F, Capasso F 1993. Nitric oxide and castor oil-induced diarrhea. $J$ Pharmacol Exp Ther 268: 291-295.

Mascolo N, Izzo AA, Gaginella TS, Capasso F 1996. Relationship between nitric oxide and plateletactivating factor in castor oil-induced mucosal injury in the rat duodenum. $\mathrm{N}-\mathrm{S}$ Arch Pharmacol 353: 680684 .

Melo SF, Soares SF, da Costa RF, da Silva CR, de Oliveira MB, Bezerra RJ, Caldeira-de-Araujo A, BernardoFilho M 2001. Effect of the Cymbopogon citrates, Maytenus ilicifolia and Baccharis genistelloides extracts against the stannous chloride oxidative damage in Escherichia coli. Mutat Res 496: 33-38.

Morimoto Y, Shimohara K, Oshima S, Sukamoto T 1991. Effects of the new anti-ulcer agent KB-5492 on experimental gastric mucosal lesions and gastric mucosal defensive factors, as compared to those of teprenone and cimetidine. Jpn J Pharmacol 57: 495505

Natale G, Lazzeri G, Blandizzi C, Gherardi G, Lenzi P, Pellegrini A, Del Tacca M 2001. Seriate histomorphometry of whole rat stomach: an accurate and reliable method for quantitative analysis of mucosal damage. Toxicol Appl Pharmacol 174: 17-26.

Oates PJ, Hakkinen JP 1988. Studies on the mechanisms of ethanol-induced gastric damage in rats. Gastroenterol 94: $10-12$.

Pedernera AM, Guardia T, Calderón CG, Rotelli AE, De la Rocha NE, Genaro S, Pelzer LE 2006. Antiulcerogenic and anti-inflammatory activity of the methanolic extract of Larrea divaricata Cav. in rat. $J$ Ethnopharmacol 105: 415-420.

Perez-Victoria JM, Tincusi BM, Jimenez IA, Bazzocchi IL Gupta MP, Castanys S, Gamarro F, Ravelo AG 1999. New natural sesquiterpenes as modulators of daunomycin resistance in a multidrug-resistant Leishmania tropica line. J Med Chem 42: 43884393.

Pinto A, Calignano A, Mascolo N, Sorrentino R, Biondi A, Izzo AA, Capasso F 1992. Time course of PAF formation by gastrointestinal tissue in rats after castor oil challenge. J. Pharm Pharmacol 44: 224-226. 
Raffa RB, Rawls SM, Beyzarov EP, 2006. Atlas de Farmacologia de Netter. Artmed. Porto Alegre, Brasil, p.181

Rao VSN, Santos FA, Sobreira TT, Souza MF, Melo CL, Silveira ER 1997. Investigations on the gastroprotective and antidiarrhoeal properties of ternatin, a tetramethoxyflavone from Egletes viscose. Planta Med 63: 146-149.

Rocha CS, Pimentel RMM, Randau KP, Xavier HS 2004. Morfoanatomia de folhas de Maytenus rigida Mart. (Celastraceae); uma espécie utilizada como medicinal no nordeste do Brasil, Acta Farm Bonaerense 23: 472-476.

Silva JL, Silva RP, Jorge RM, Fátima-Silva GD, Vieira-Filho SA, Fonseca APND, Tagliati CA 2005. Avaliação da atividade antiulcerogênica da Maytenus truncata Reiss (Celastraceae). Rev Bras Farmacogn 15: 3035.

Souza Brito ARM 1995. Manual de Ensaios Toxicológicos in vivo. Editora da Unicamp, Campinas, São Paulo, 1522.

Souza-Formigoni ML, Oliveira MG, Monteiro MG, da Silveira-Filho NG, Braz S, Carlini EA 1991. Antiulcerogenic effects of two Maytenus species in laboratory animals. $J$ Ethnopharmacol 34: 21-27.

Szelenyi I, Thiemer K 1978. Distention ulcer as a model for testing of drugs for ulcerogenic side effects. Arc Toxicol 41: 99-105.

Tabach R, Oliveira WP 2003. Evaluation of the antiulcerogenic activity of a dry extract of Maytenus ilicifolia Martius ex. Reiss produced by a jet spouted bed dryer. Pharmazie 58: 573-576.

To KF, Chan FKL, Chen ASL, Lee TL, Ng YP, Sung JJY 2001. Up-regulation of cyclooxygenase-1 and -2 in human gastric ulcer. Aliment Pharm Therap 15: 25-34.

Vellosa JCR, Khalil NM, Formenton VAF, Ximenes VF, Fonseca LM, Furlan M, Brunetti IL, Oliveira OMMF 2006. Antioxidant activity of Maytenus ilicifolia root bark. Fitoterapia 77: 243-244.

Ward PA 1994. Inflammation. In: Pathology. Rubin E, Farber JL, eds. Philadelpia: Lippincott Company. 33-66.

Winter CA, Risley EA, Nuss GW 1962. Carrrageenaninduced edema in hind paw of rat as an assay for anti-inflammatory drugs. Prog Soc Biol Med 11: 544-547. 